\section{Nitrogen Release Properties of Controlled-release Fertilizers during Tomato Production}

\author{
Luther C. Carson, Monica Ozores-Hampton ${ }^{1}$, and Kelly T. Morgan \\ University of Florida, Southwest Florida Research and Education Center \\ (SWFREC), Immokalee, FL 34142
}

\section{Jerry B. Sartain \\ University of Florida, Soil and Water Science Department, Gainesville, FL 32611}

Additional index words. Solanum lycopersicum, enhanced-efficiency, slow-release, BMP, pouch method, release duration

\begin{abstract}
Determination of nutrient release duration from controlled-release fertilizers (CRFs) or soluble fertilizers encapsulated in polymer, resin, or sulfur covered fertilizer coated with a polymer differs among manufacturers, but may be determined as $75 \%$ to $80 \%$ nitrogen $(\mathrm{N})$ release at a constant temperature (e.g., 20 to $25{ }^{\circ} \mathrm{C}$ ). Increases or decreases in temperature compared with the manufacturer release determination temperature increase or decrease CRF $N$ release; thus, coated fertilizer may release more rapidly than stated during the fall season when soil temperatures in seepage-irrigated tomato (Solanum lycopersicum) production can reach $40.1^{\circ} \mathrm{C}$. The objectives of this study were to evaluate $\mathrm{N}$ release duration of CRFs by measuring $\mathrm{N}$ release from $\mathrm{CRF}$ s incubated in pouches under polyethylene mulch-covered raised beds and to determine the CRF duration suitable for incorporation into a fall tomato fertility program. In 2011 and 2013, 12 and 14 CRFs from Agrium Advanced Technologies, Everris, Florikan, and ChissoAsahi Fertilizer were sealed in fiberglass mesh pouches $(12.7 \times 14 \mathrm{~cm})$ that were buried 10 $\mathrm{cm}$ below the bed surface in a tomato crop grown using commercial production practices. A data logger collected soil temperature $10 \mathrm{~cm}$ below the bed surface. Pouches were collected and $\mathrm{N}$ content was measured eight times through two fall seasons. A nonlinear regression model was fit to the data to determine $\mathrm{N}$ release rate. During the 2011 and 2013 seasons, minimum, average, and maximum soil temperatures were 21.2 and 19.2, 25.7 and 23.5, and 32.2 and $27.7^{\circ} \mathrm{C}$, respectively. Seasonal total CRF $N$ release was between $77.6 \%$ and $93.8 \%$ during 2011 and $58.3 \%$ and $94.3 \%$ in 2013. In 2011, PCU90 and in 2013, PCU90 and PCNPK120 had the highest seasonal total percentage $N$ release (PNR) and FL180 had the lowest in both years. A nonlinear regression fit $\mathrm{N}$ release from $\mathrm{CRF}$ with $\boldsymbol{R}^{\mathbf{2}}=0.85$ to 0.99 during 2011 and 0.49 to 0.99 during 2013. Nitrogen release from all CRFs was faster than the manufacturer's stated release, probably as a result of high fall bed temperatures. A CRF or CRF mixture containing CRFs of 120- to 180-day release duration may be recommended, but the CRFs must release greater than $75 \% \mathrm{~N}$ during the season.
\end{abstract}

A series of best management practices, including use of CRF, has been implemented for vegetable and agronomic crops by the Florida Department of Agriculture and Consumer Services in response to the Federal Clean Water Act of 1972 and the Florida Restoration Act of 1999 (Bartnick et al., 2005). Controlled-release fertilizers are soluble fertilizer (SF) coated in polymer, resin, or sulfur-coated urea in a polymer coating (Trenkel, 2010).

Field measurements of CRF N release have been made by researchers using the field pouch method, which consists of a known mass of CRF (e.g., $3.5 \mathrm{~g} \mathrm{~N}$ ) sealed inside fiberglass mesh pouches that may be buried inside a polyethylene mulched or open bed vegetable systems and removed at prearranged dates (Carson

Received for publication 26 Aug. 2014. Accepted for publication 15 Oct. 2014.

${ }^{1}$ To whom reprint requests should be addressed; e-mail Ozores@ufl.edu. the most influential factor (Carson and Ozores-Hampton, 2013). Under laboratory conditions, Lamont et al. (1987) measured N release at nine temperatures from 5 to $45^{\circ} \mathrm{C}$ and found a quadratic release response with temperature and time. In a similar study, Gandeza et al. (1991) demonstrated a doubling of the percentage $\mathrm{N}$ release (PNR) with each $10^{\circ} \mathrm{C}$ rise in temperature from 10 to $30^{\circ} \mathrm{C}$. Thus, a CRF release duration will increase or decrease inversely with soil temperatures that differ from CRF manufacturer label specification. Controlled-release fertilizer manufacturers determine nutrient release duration in water at a constant $20.0,21.1$, and $25.0^{\circ} \mathrm{C}$, respectively (Agrium Advanced Technologies, 2010; Everris, 2013; Florikan ESA, 2012a, 2012b). However, the average daily soil temperatures under a polyethylene mulch-covered, raised vegetable bed in south Florida were greater than $23.9^{\circ} \mathrm{C}$ for 8 weeks after bedding and were as high as $40.1{ }^{\circ} \mathrm{C}$ during the daytime in a fall tomato (Solanum lycopersicum) season (Carson et al., 2012a, 2013). Thus, high soil temperatures during the fall will affect CRF release duration used in tomato production. Therefore, selection of a CRF with too low of a nutrient release duration may result in slow nutrient release causing plant nutrient deficiencies, low plant growth, and reduced yield. In contrast, selection of a CRF with too high of a high nutrient release rate may result in increased soil electrical conductivity, plant toxicity and injury, and the loss of CRF benefits (Shaviv, 1996). Because CRF N release durations, independent of manufacturers' labeling, have not been published for fall production in Florida, the objectives of this study were to evaluate $\mathrm{N}$ release duration of CRFs by measuring $\mathrm{N}$ release from 90 - to $180-\mathrm{d}$ release CRFs incubated in pouches under polyethylene mulch-covered raised beds and to determine the CRF duration suitable for incorporation into a fall tomato fertility program.

\section{Material and Methods}

and Ozores-Hampton, 2012). After collection, the $\mathrm{N}$ content remaining in the CRF prills is measured to determine the amount of $\mathrm{N}$ remaining and the $\mathrm{N}$ release rate. The mesh pouch allows for soil to CRF prill contact, which may affect CRF N release rate. For instance, pouches with $1.2-\mathrm{mm}^{2}$ openings had greater $\mathrm{N}$ release compared with a weed-block material with $0.07-\mathrm{mm}^{2}$ openings (Wilson et al., 2009).

Several factors influence nutrient release from CRFs including soil temperature, moisture content, osmotic potential $\left(\psi_{\mathrm{S}}\right)$, nutrient composition, coating thickness, and prill diameter (Carson and Ozores-Hampton, 2013). Manufacturers of CRF manipulate the nutrient release duration of resin-coated fertilizer, polymer-coated fertilizer (PCF), and polymer sulfur-coated urea (PSCU) by adjusting coating thickness and composition with thicker coatings having longer release durations (Carson and Ozores-Hampton, 2013). However, in irrigated vegetable production, soil temperature may be considered
Two concurrent CRF field studies were conducted during each Fall 2011 and 2013 on a commercial tomato farm near Immokalee, FL (lat. $26^{\circ} 14^{\prime} 5^{\prime \prime} \mathrm{N}$, long. $81^{\circ} 28^{\prime} 55^{\prime \prime} \mathrm{W}$ ). The soil at the study location was Basinger fine sand (hyperthermic Spodic Psammaquents), which permitted seepage irrigation. The field configuration, bed preparation and fertilization, and fresh market tomato production practices are described in Carson et al. (2014a, 2014b), and dates relevant to these trials are in Table 1.

The two concurrent CRF studies each contained six and seven CRFs in 2011 and 2013, respectively, for a total of 12 CRFs in 2011 and 14 CRFs in 2013 (Table 2). The CRF fall mixes (M112, M168, and M224) are $\mathrm{CRF}, \mathrm{SF}$, and filler mixes that when applied at $1493 \mathrm{~kg} \cdot \mathrm{ha}^{-1}$ supply 112,168 , and 224 $\mathrm{kg} \cdot \mathrm{ha}^{-1} \mathrm{CRF} \mathrm{N}$; however, different SF and filler amounts in the pouch may have affected the PNR in 2011. Therefore, a CRF mix (FLmix) 
Table 1. Collection dates and days after placement (DAP) for pouches containing controlled-release fertilizer incubated in white polyethylene mulch-covered raised tomato beds during Fall 2011 and 2013 in Immokalee, FL.

\begin{tabular}{|c|c|c|c|c|c|c|c|c|c|c|c|}
\hline \multirow[b]{2}{*}{$\mathrm{Yr} /$ study } & \multirow{2}{*}{$\begin{array}{l}\text { Bedding } \\
\text { date }\end{array}$} & \multirow{2}{*}{$\begin{array}{c}\text { Planting } \\
\text { date }\end{array}$} & \multirow{2}{*}{$\begin{array}{c}\text { Pouch } \\
\text { placement }\end{array}$} & \multicolumn{8}{|c|}{ Collection date (DAP) } \\
\hline & & & & 1 & 2 & 3 & 4 & 5 & 6 & 7 & 8 \\
\hline $2011 / 2$ & 15 Aug. & 3 Sept. & 15 Aug. & 22 Aug. (7) & 30 Aug. (15) & 13 Sept. (29) & 26 Sept. (42) & 14 Oct. (60) & 14 Nov. (91) & 13 Dec. (120) & 22 Dec. (129) \\
\hline $2013 / 1$ and 2 & 20 Sept. & 8 Oct. & 24 Sept. & 1 Oct. (7) & 8 Oct. (14) & 21 Oct. (27) & 6 Nov. (43) & 21 Nov. (58) & 23 Dec. $(90)$ & 21 Jan. (119) & 23 Jan. (121) \\
\hline
\end{tabular}

Table 2. Controlled-release fertilizers (CRFs) placed in pouches and incubated in white polyethylene mulch-covered raised tomato beds during Fall 2011 and 2013 in Immokalee, FL.

\begin{tabular}{|c|c|c|c|c|c|}
\hline Study & $\mathrm{CRF}^{\mathrm{z}}$ & Abbreviation & Release duration & Grade $^{y}$ & Manufacturer \\
\hline 1 & PCU & PCU90 & 90 & $44-0-0$ & AAT \\
\hline 1 & PCNPK & PCNPK120 & 120 & $19-2.6-10.8$ & AAT \\
\hline 1 & PCU & PCU180 & 180 & 43-0-0 & AAT \\
\hline 1 & PSCU & PSCU & 180 & $37-0-0$ & Everris NA \\
\hline 1 & RCNPK & RCNPK & 120 & $19-2.6-10$ & Everris NA \\
\hline 2 & $\mathrm{PCN}$ & FL100 & 100 & 28-0-0 & CAFC \\
\hline $2^{w}$ & PCM & FLmix & 100 to 180 & $19.2-0-11.3$ & Florikan ESA \\
\hline 2 & Fall Mix 112 & M112 & 100 to 180 & $7.5-3.6-10.3$ & Florikan ESA \\
\hline 2 & Fall Mix 168 & M168 & 100 to 180 & $12.3-3.6-10.3$ & Florikan ESA \\
\hline 2 & Fall Mix 224 & M224 & 100 to 180 & $15-3.6-10.3$ & Florikan ESA \\
\hline
\end{tabular}

${ }^{2} \mathrm{PCU}=$ polymer-coated urea; $\mathrm{PCNPK}=$ polymer-coated compound nitrogen $(\mathrm{N})$, phosphorus $(\mathrm{P})$, and potassium $(\mathrm{K})$ fertilizer; PSCU = polymer sulfur-coated urea; $\mathrm{RCNPK}=$ resin-coated compound N, $\mathrm{P}$, and $\mathrm{K}$ fertilizer; $\mathrm{PCN}=$ polymer-coated $\mathrm{N} ; \mathrm{PCNK}=$ polymer-coated potassium nitrate; $\mathrm{PCM}=$ polymer-coated mix containing FL100, FL140, and FL180; M112, M168, and M224 are mixes of CRF and SF that when applied at $1493 \mathrm{~kg} \cdot \mathrm{ha}^{-1}$ supply 112,168 , and $224 \mathrm{~kg} \cdot \mathrm{ha}^{-1} \mathrm{CRF}$ $\mathrm{N}$.

${ }^{y}$ Fertilizer grade $=(\% \mathrm{~N}-\% \mathrm{P}-\% \mathrm{~K})$

${ }^{x}$ Agrium Advnaced Technology (AAT), Loveland, CO; Everris NA, Inc., Dublin, OH; Florikan ESA, LLC., Sarasota, FL; Chisso-Asahi Fertilizer Co. Ltd. (CAFC), Tokyo, Japan.

wPCU180NPK and FLmix were included in 2013; all other CRFs were tested in both years.

Table 3. Minimum, mean, and maximum air temperature and soil temperatures at $10 \mathrm{~cm}$ below the bed surface during Fall 2011 and 2013 in Immokalee, FL.

\begin{tabular}{|c|c|c|c|c|c|c|c|c|c|c|c|c|}
\hline \multirow{2}{*}{ Week ending ${ }^{z}$} & \multicolumn{6}{|c|}{ Air temp } & \multicolumn{6}{|c|}{ Soil temp } \\
\hline & \multicolumn{2}{|c|}{ Minimum } & \multicolumn{2}{|c|}{ Mean } & \multicolumn{2}{|c|}{ Maximum } & \multicolumn{2}{|c|}{ Minimum } & \multicolumn{2}{|c|}{ Mean } & \multicolumn{2}{|c|}{ Maximum } \\
\hline 9 Aug. & 22.1 & - & 27.6 & - & 38.3 & - & 25.7 & - & 30.3 & - & 40.1 & - \\
\hline 23 Aug. & 22.4 & - & 26.9 & - & 37.3 & - & 24.7 & - & 29.7 & - & 40.1 & - \\
\hline 30 Aug. & 22.8 & - & 27.1 & - & 35.0 & - & 25.0 & - & 29.3 & - & 37.6 & - \\
\hline 6 Sept. & 21.7 & - & 26.5 & - & 36.2 & - & 24.5 & - & 28.5 & - & 36.7 & - \\
\hline 13 Sept. & 22.0 & - & 27.4 & - & 37.4 & - & 24.7 & - & 30.6 & - & 39.1 & - \\
\hline 4 Oct. & 15.0 & 20.3 & 25.3 & 26.3 & 35.7 & 33.2 & 22.5 & 24.7 & 28.6 & 28.4 & 36.0 & 34.4 \\
\hline 11 Oct. & 15.9 & 17.6 & 24.2 & 25.1 & 33.1 & 34.3 & 22.2 & 23.7 & 26.4 & 27.8 & 32.7 & 33.2 \\
\hline 18 Oct. & 20.3 & 17.8 & 24.3 & 24.6 & 33.5 & 33.3 & 23.5 & 23.4 & 26.0 & 27.5 & 32.7 & 32.2 \\
\hline 25 Oct. & 10.2 & 14.7 & 20.0 & 24.3 & 28.4 & 35.6 & 18.2 & 21.2 & 23.1 & 27.3 & 28.2 & 33.2 \\
\hline 1 Nov. & 14.0 & 14.1 & 22.5 & 22.3 & 30.8 & 32.2 & 20.2 & 20.7 & 24.0 & 24.6 & 28.0 & 29.4 \\
\hline 8 Nov. & 10.1 & 13.3 & 20.1 & 22.5 & 29.7 & 31.2 & 17.2 & 20.2 & 22.4 & 24.5 & 27.7 & 29.7 \\
\hline 15 Nov. & 9.7 & 11.7 & 20.0 & 21.9 & 32.0 & 30.6 & 16.5 & 18.9 & 21.7 & 23.6 & 26.7 & 26.9 \\
\hline 20 Dec. & 9.8 & 6.4 & 19.2 & 18.7 & 29.0 & 30.1 & 15.7 & 16.7 & 20.7 & 20.6 & 24.2 & 23.9 \\
\hline 27 Dec. & 11.9 & 13.4 & 20.0 & 21.5 & 29.4 & 31.8 & 17.2 & 19.4 & 20.5 & 22.0 & 24.2 & 24.9 \\
\hline 3 Jan. & - & 7.8 & - & 20.4 & - & 30.8 & - & 16.9 & - & 21.9 & - & 23.7 \\
\hline $10 \mathrm{Jan}$. & - & 6.8 & - & 17.4 & - & 30.1 & - & 14.7 & - & 18.6 & - & 23.7 \\
\hline 17 Jan. & - & -0.3 & - & 17.2 & - & 29.6 & - & 13.2 & - & 20.0 & - & 24.4 \\
\hline 24 Jan. & - & -1.9 & - & 13.1 & - & 26.7 & - & 11.9 & - & 16.2 & - & 20.4 \\
\hline Average & 15.7 & 11.5 & 23.4 & 21.6 & 33.1 & 31.5 & 21.2 & 19.2 & 25.7 & 23.5 & 32.2 & 27.7 \\
\hline
\end{tabular}

${ }^{z}$ Collection dates began on 3 Aug. 2011 and 24 Sept. 2013 and ended on 22 Dec. 2011 and 23 Jan. 2014.

was added in 2013, which contained CRFs in a ratio equivalent to the fall mixes that were composed of FL100, FL140, and FL180. Fiberglass window screen $(18 \times 14$-mesh or 39 pores $\left./ \mathrm{cm}^{2}\right)$ rectangles $(15.2 \times 30.5 \mathrm{~cm})$ were folded in half and sealed on two sides using a clothes iron (Model F210; Black \& Decker, New Britain, CT). Controlled-release fertilizer samples containing $3.5 \mathrm{~g} \mathrm{~N}$ were placed inside the pouches and the last side was sealed, which resulted in internal dimensions of $\approx 12.7 \times 14.0 \mathrm{~cm}$ (Carson et al., 2013). At bed formation in
2011 and $5 \mathrm{~d}$ after bedding in 2013 (to reduce personal protective equipment requirements), the pouches were placed level, $10 \mathrm{~cm}$ below the bed surface, in the center bed of a three-bed, 1.5-m-long plots. The studies were randomized complete block design with 
four replications and eight collection dates. Pouches in the experimental unit, e.g., a set of six or seven pouches representing each CRF, were placed randomly in the $\mathrm{pl}$ ifter pouches were collected (Table 1), $\mathrm{t}$ uch contents were dried in beakers at ambient temperature and stored until analysis (Carson et al., 2012b). In preparation for CRF $\mathrm{N}$ analysis, the pouch contents were ground in a blender (Model 36BL23; Waring Commercial, New Hartford, CT) with $300 \mathrm{~mL}$ deionized (DI) water to destroy the CRF coating and dissolve the SF. Samples were diluted to $500 \mathrm{~mL}$ using DI water, filtered using Whatman no. 42 filter paper, and frozen until $\mathrm{N}$ analysis. The solution was analyzed for total soluble $\mathrm{N}$ by pyrolysis and chemiluminescence using an Antek 9000 $\mathrm{N}$ analyzer (Pac. Co., Houston, TX) in 2011. In 2013, nitrate-N and ammonium-N were measured by salicylate-hypochlorite, cadmium reduction using a Flow Analyzer (QuikChem 8500; Lachat Co., Loveland, CO) at $660 \mathrm{~nm}$ and $520 \mathrm{~nm}$, respectively, and urea-N was measured by modified diacetyl monoxime methods using a DR/4000U Spectrophotometer (Hach Co., Loveland, CO) at $527 \mathrm{~nm}$ (Sato et al., 2009; Sato and Morgan, 2008). The results for nitrate- $\mathrm{N}$, ammonium-N, and urea-N were summed to determine total CRF $\mathrm{N}$ remaining in the prill. The $\mathrm{N}$ release results were expressed in cumulative PNR.

Weather data were obtained through the Florida Automated Weather Network (FAWN) and a Watchdog data logger (Model B100;
Spectrum Technologies Inc., Plainfield, IL) collected soil temperature hourly $10 \mathrm{~cm}$ below the bed surface through the tomato season.

Analysis of variance and orthogonal contrasts were performed on PNR data by collection date using the general linear model procedure in SAS (Version 9.3; SAS Institute Inc., Cary, NC). Year and CRF were considered main effects and year $\times$ CRF was an interaction effect. The non-linear regression procedure in SAS was used to determine the $\mathrm{N}$ release rate by fitting a CRF $\mathrm{N}$ release curve, which was also used to calculate the days to $75 \% \mathrm{~N}$ release (Medina et al., 2008; Sartain et al., 2004a, 2004b). The non-linear regression model was:

$$
\operatorname{PNR}=a-(a-b) \times e^{-c t}
$$

where $\mathrm{a}=$ the maximum PNR, $\mathrm{b}=$ the intercept or value when time $(\mathrm{t})=0$, and $\mathrm{c}=$ the rate of increase (Medina, 2011; Sartain et al., 2004a, 2004b). Because $\mathrm{t}=0$ data theoretically equals zero, intercept data were not included in the model, but intercept values were determined. An $R^{2}$ statistic for the non-linear regression was calculated, and a Student's $t$ test was used to compare nonlinear regression coefficients between years for each CRF.

\section{Results and Discussion}

Weather conditions. The minimum, average, and maximum air temperatures from placement until last collection were 6.4, 23.4, and $38.3{ }^{\circ} \mathrm{C}$ and $-1.9,21.6$, and $35.6{ }^{\circ} \mathrm{C}$ during 2011 and 2013, respectively. The 2011 and 2013 average air temperatures during the incubation period were similar to the moving 10-year average temperatures for the same period, which averaged 23.1 and $21.0^{\circ} \mathrm{C}$, respectively (FAWN, 2013). Total rainfall during the incubation period was greater in 2011 than 2013 with 46.4 and $12.6 \mathrm{~cm}$, respectively. However, 40.3-cm rainfall accumulated during August and September, which delayed trial initiation in 2013. Both 2011 and 2013 accumulated lower than average rainfall during the incubation period compared with the 10-year average of 49.0 and $31.5 \mathrm{~cm}$. The average daily air temperatures first went lower than Agrium Advanced Technologies Inc., Everris Intl., and Florikan ESA LLC. and Chisso-Asahi Fertilizer Co. specifications of 20.0, 20.1, and 25.0 after 10, 10, and 8 weeks in 2011 and 9, 9, and 1 week in 2013, respectively. Because CRF prills directly contact the soil, they are highly affected by soil temperature; however, because air temperature and soil temperature highly correlate, air temperature may reliably indicate temperatures effect on CRF (Carson et al., 2014a, 2014b).

Soil temperature. The minimum, average, and maximum soil temperature $10 \mathrm{~cm}$ below the bed surface decreased during the seasons ranging from 25.7 to $14.7^{\circ} \mathrm{C}, 30.6$ to $20.0^{\circ} \mathrm{C}$, and 40.1 to $24.2{ }^{\circ} \mathrm{C}$ in 2011 and 25.2 to

Table 4. Percentage nitrogen $(\mathrm{N})$ release from controlled-release fertilizers (CRFs) incubated in pouches $10 \mathrm{~cm}$ below the surface of a white polyethylene mulchcovered raised bed during Fall 2011 and 2013 tomato production seasons in Immokalee, FL.

\begin{tabular}{|c|c|c|c|c|c|c|c|c|c|}
\hline \multirow[b]{3}{*}{$\mathrm{CRF}^{\mathrm{y}}$} & \multirow[b]{3}{*}{ Yr } & \multicolumn{8}{|c|}{ Collection date DAP $(2011-13)^{\mathrm{z}}$} \\
\hline & & $1(7 / 7)$ & $2(15 / 14)$ & $3(28 / 27)$ & $4(42 / 43)$ & $5(61 / 58)$ & $6(91 / 90)$ & $7(120 / 119)$ & $8(134 / 121)$ \\
\hline & & \multicolumn{8}{|c|}{ 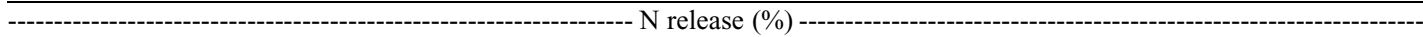 } \\
\hline \multirow[t]{2}{*}{ PCU90 } & 2011 & 22.9 & 37.9 & 64.3 & 77.8 & 82.4 & 89.2 & 92.6 & 93.8 \\
\hline & 2013 & 16.0 & 35.7 & 62.4 & 65.3 & 70.3 & 87.6 & 94.3 & 90.0 \\
\hline \multirow[t]{2}{*}{ PCU120 } & 2011 & 19.5 & 33.0 & 48.6 & 70.6 & 77.3 & 84.5 & 88.3 & 91.1 \\
\hline & 2013 & 41.2 & 44.5 & 59.4 & 55.9 & 68.6 & 81.9 & 79.9 & 76.0 \\
\hline \multirow[t]{2}{*}{ PCNPK120 } & 2011 & 27.7 & 37.0 & 51.7 & 71.4 & 79.2 & 83.3 & 86.7 & 90.2 \\
\hline & 2013 & 47.5 & 61.6 & 71.1 & 79.7 & 85.0 & 94.8 & 94.3 & 94.0 \\
\hline \multirow[t]{2}{*}{ PCU180 } & 2011 & 23.0 & 24.4 & 52.1 & 69.0 & 81.8 & 85.6 & 88.7 & 91.5 \\
\hline & 2013 & 29.5 & 38.6 & 64.4 & 51.6 & 73.0 & 80.6 & 83.8 & 82.3 \\
\hline \multirow[t]{2}{*}{ PCNPK 180} & 2011 & - & - & - & - & - & - & - & - \\
\hline & 2013 & 36.5 & 34.4 & 42.6 & 51.9 & 61.6 & 78.3 & 83.4 & 85.9 \\
\hline \multirow[t]{2}{*}{ PSCU } & 2011 & 31.9 & 33.6 & 36.2 & 45.9 & 60.6 & 69.5 & 77.6 & 78.2 \\
\hline & 2013 & 41.5 & 40.8 & 44.6 & 43.3 & 35.8 & 60.8 & 63.4 & 64.0 \\
\hline \multirow[t]{2}{*}{ RCNPK } & 2011 & 29.3 & 42.6 & 52.3 & 69.3 & 76.8 & 85.5 & 87.6 & 90.2 \\
\hline & 2013 & 50.5 & 60.3 & 65.6 & 70.7 & 78.7 & 92.4 & 93.9 & 91.6 \\
\hline \multirow[t]{2}{*}{ FL100 } & 2011 & 57.5 & 69.4 & 80.0 & 88.2 & 92.0 & 86.0 & 87.2 & 91.5 \\
\hline & 2013 & 60.1 & 65.0 & 77.3 & 81.2 & 87.4 & 90.1 & 94.0 & 92.7 \\
\hline \multirow[t]{2}{*}{ FL140 } & 2011 & 52.1 & 68.8 & 87.0 & 88.5 & 94.3 & 86.9 & 89.0 & 91.3 \\
\hline & 2013 & 65.5 & 65.6 & 75.4 & 78.0 & 82.9 & 86.3 & 87.4 & 88.0 \\
\hline \multirow[t]{2}{*}{ FL180 } & 2011 & 6.6 & 10.0 & 63.3 & 61.3 & 87.5 & 62.5 & 75.1 & 77.6 \\
\hline & 2013 & 19.0 & 19.1 & 43.0 & 44.4 & 41.1 & 50.1 & 59.4 & 58.3 \\
\hline \multirow[t]{2}{*}{ FLmix } & 2011 & - & - & - & - & - & - & - & - \\
\hline & 2013 & 64.3 & 61.5 & 66.4 & 74.5 & 69.1 & 79.4 & 81.9 & 77.4 \\
\hline \multirow[t]{2}{*}{ M112 } & 2011 & 14.2 & 34.5 & 47.9 & 54.5 & 61.1 & 78.2 & 81.4 & 82.5 \\
\hline & 2013 & 47.2 & 49.8 & 49.8 & 68.0 & 64.5 & 77.1 & 84.9 & 80.5 \\
\hline \multirow[t]{2}{*}{ M168 } & 2011 & 38.4 & 50.3 & 68.1 & 71.1 & 75.8 & 81.9 & 84.5 & 88.0 \\
\hline & 2013 & 57.2 & 64.3 & 62.6 & 72.3 & 77.3 & 81.6 & 88.8 & 87.6 \\
\hline \multirow[t]{2}{*}{ M224 } & 2011 & 45.9 & 57.2 & 70.8 & 80.2 & 80.8 & 83.2 & 84.6 & 86.8 \\
\hline & 2013 & 48.5 & 58.5 & 69.7 & 74.9 & 79.0 & 87.3 & 85.9 & 86.2 \\
\hline
\end{tabular}

${ }^{\mathrm{z}}$ The $2011 \mathrm{~d}$ after placement (DAP) number is an average between the DAP for the two studies rounded to the nearest whole number of days.

yPCU9 $=$ polymer-coated (PC) urea, 90-d release (DR); PCU120 = PC urea, 120 DR; PCNPK120 = PC nitrogen, phosphorus, and potassium (NPK), 120 DR; PCU180 = PC urea, 180 DR; PSCU = polymer sulfur-coated urea, 180 DR; RCNPK = resin-coated NPK, 120 DR; FL100 = PC urea, ammonium nitrate, 100 DR; FL140 $=$ PC urea and ammonium nitrate, 140 DR; FL180 = PC potassium nitrate, 180 DR; FLmix = mix of FL100, FL140, and FL 180; M112, M168, and M224 = mixes of CRF and SF that when applied at $1493 \mathrm{~kg} \cdot \mathrm{ha}^{-1}$ supply 112, 168, and $224 \mathrm{~kg} \cdot \mathrm{ha}{ }^{-1} \mathrm{CRF} \mathrm{N}$. 
Table 5. Contrasts of controlled-release fertilizers by collection date and coating technology from pouches incubated in white polyethylene mulch-covered raised tomato beds during Fall 2011 and 2013 in Immokalee, FL.

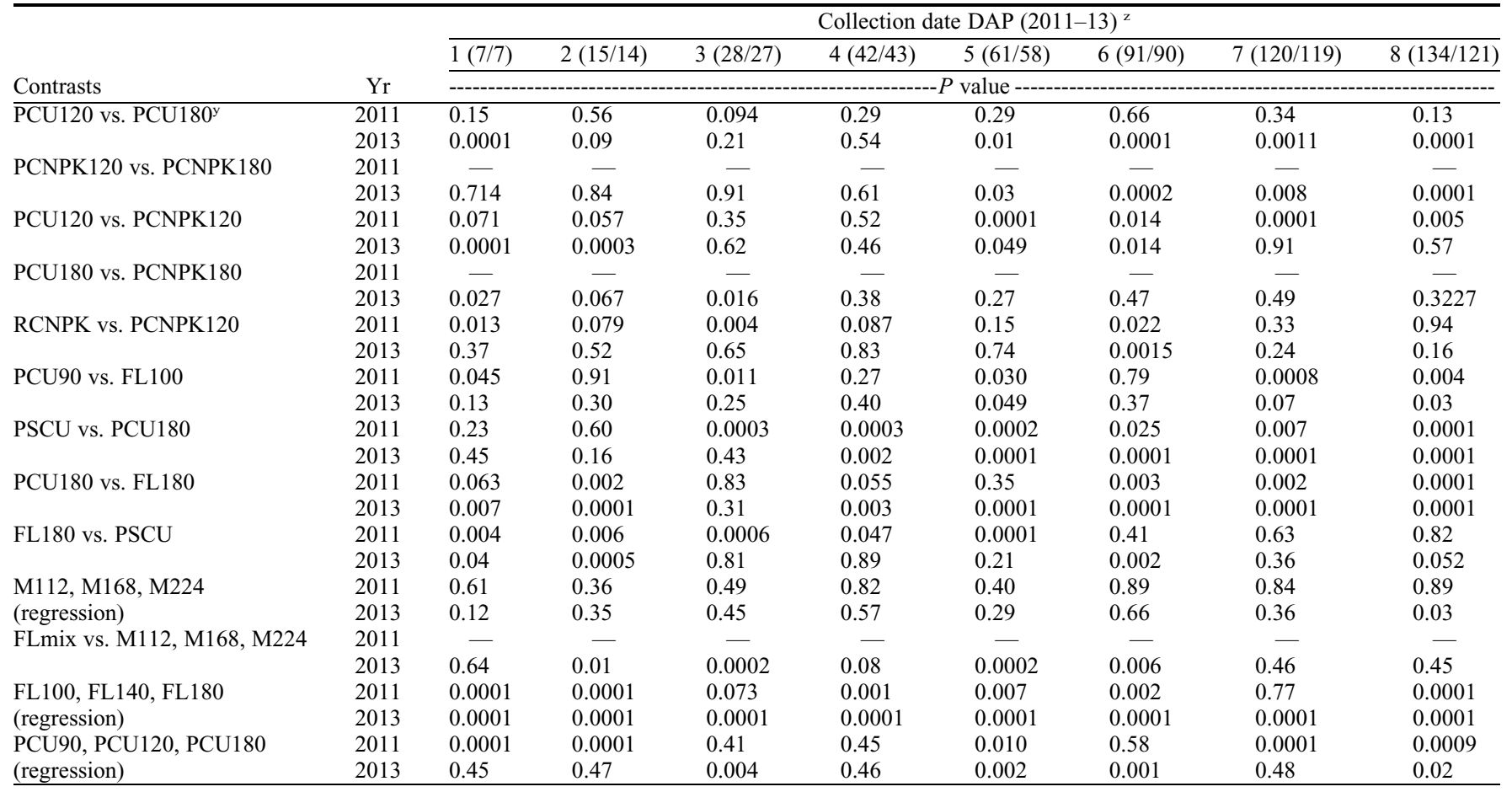

${ }^{\mathrm{z}}$ The $2011 \mathrm{~d}$ after placement (DAP) number is an average between the DAP for the two studies rounded to the nearest whole number of days.

${ }^{\mathrm{y}} \mathrm{PCU} 90$ = polymer-coated $(\mathrm{PC})$ urea, 90-d release (DR); PCU120 = PC urea, 120 DR; PCNPK120 = PC nitrogen, phosphorus, and potassium (NPK),120 DR; PCU180 = PC urea, 180 DR; PSCU = polymer sulfur-coated urea, 180 DR; RCNPK = resin-coated NPK, 120 DR; FL100 = PC urea, ammonium nitrate, 100 DR; FL140 $=$ PC urea and ammonium nitrate, 140 DR; FL180 = PC potassium nitrate, 180 DR; FLmix = mix of FL100, FL140, and FL 180; M112, M168, and M224= mixes of CRF and SF that when applied at $1493 \mathrm{~kg} \cdot \mathrm{ha}^{-1}$ supply 112,168 , and $224 \mathrm{~kg} \cdot \mathrm{ha}^{-1} \mathrm{CRF}$ N.

$11.9^{\circ} \mathrm{C}, 29.3$ to $14.8^{\circ} \mathrm{C}$, and 34.4 to $20.4^{\circ} \mathrm{C}$ in 2013, respectively (Table 3). The average daily soil temperatures were first recorded below the Agrium Advanced Technologies Inc., Everris Intl., and Florikan ESA LLC. and Chisso-Asahi Fertilizer Co. specification of $20.0,21.1$, and $25.0^{\circ} \mathrm{C}$ on 12 Nov., 5 Nov., and 17 Oct. in 2011 and 28 Nov., 28 Nov., and 24 Oct. in 2013, respectively. The average daily soil temperature was greater than the CRF manufacturer specification for more than half of the season at all temperatures in 2011 and for 20.0 and $21.1^{\circ} \mathrm{C}$ in 2013 . Also, the average soil temperature was greater than the $25{ }^{\circ} \mathrm{C} \mathrm{CRF}$ manufacturer specification in 2013 for $25 \%$ of the season. Because high soil temperatures that were above the CRF manufacturer specifications during the first $25 \%$ to $50 \%$ of the season potentially increased $\mathrm{N}$ release rate, nutrient release duration may be expected to decrease (Carson et al., 2013; Carson and Ozores-Hampton, 2013; Gandeza et al., 1991; Huett and Gogel, 2000).

Measured nitrogen release from CRFs incubated the field pouch method. When data were analyzed without the two treatments added in 2013, there were interactions $(P<$ 0.05 ) between CRF and year in six of eight collection dates. The main effects, CRF and year, were significant $(P<0.05)$ in eight and four collection dates, respectively. Therefore, PNR results were presented by year. The PNR at the first collection date ranged from $6.6 \%$ to $57.5 \%$ in 2011 and $16.0 \%$ to $65.5 \%$ in 2013 (Table 4). At the end of the season, PNR ranged from $77.6 \%$ to $93.8 \%$ during 2011 and $58.3 \%$ to $94.0 \%$ in 2013. In 2011, PCU90 and in 2013, PCU90 and PCNPK120 had the highest season total PNR, whereas FL180 had the lowest PNR during both seasons. The PNR from PCU120 and PCU180 was not different at any collection date during 2011 but was significantly different at collection dates one and five through eight in 2013 (Table 5). Similarly, PCNPK120 and PCNPK180 had a different PNR at collection dates five through eight in 2013. Perhaps, the high soil temperatures during the early fall accelerated the $\mathrm{N}$ release rate of 180-d release PCFs for a similar PNR compared with 120-d release PCFs. The PNR from PCU120 and PCNPK120 was similar during collection dates one through four and three, four, seven, and eight in 2011 and 2013, respectively. With the exception of collection dates one and three, no PNR differences were found for PCU180 and PCNPK180 in 2013. At three nonadjacent and one collection date during the 2011 and 2013 seasons, RCNPK and PCNPK120 were significantly different. Nitrogen release from PCU90 and FL100 were significantly different in 2011 but not in 2013, although numerically the $\mathrm{N}$ release was different. Overall, the CRF technology had a greater impact on PNR from the 180-d release CRFs (PSCU, PCU180, and FL180) compared with the impact of constituent SF within 180-d CRF technologies (PCU180 and PCNPK180). The fall season mixes (M112, M168, and M224) were not linearly related, and PNR from the fall mixes were different from FLmix at four collection dates. At six and eight collection dates in 2011 and 2013, respectively, PNR from the components of the fall mix (FL100, FL140, and FL180) were linearly related; thus, CRF PNR decreased with increasing release duration in 2011 and 2013. Similarly, PNR from PCU90, PCU120, and PCU180 were linearly related at the five and four collection dates in 2011 and 2013, respectively.

The soil temperature during these seasons averaged $2.2^{\circ} \mathrm{C}$ lower in 2013 compared with 2011 , which was the result of the delayed trial start date in 2013. The lower average soil temperatures in 2013 probably caused the lower PNR found among CRFs when compared with 2011(Carson and OzoresHampton, 2013). Diverse coating technologies released $\mathrm{N}$ differently among the $180-\mathrm{d}$ CRF products suggesting that technologies responded differently to increases in temperature during the tomato season. However, the 120-d release CRFs, especially RCNPK and PCNPK120, were similar at more collection dates than different; thus, perhaps the increased temperature affected these coating technologies similarly. The resemblance among N release from PCU90 and FL100 in 2013 was probably related to underlying variability rather than differences in PNR. In 2013, a numerically greater PNR was found with FLmix than M112, M168, and M224 at collections one through six, one and two, and one and two, respectively. Perhaps the SFs and fillers reduced the osmotic potential and $\mathrm{N}$ release during the early season in M112, with 
Table 6. Nonlinear regression analysis of nitrogen $(\mathrm{N})$ release from controlled-release fertilizers (CRFs) incubated in pouches $10 \mathrm{~cm}$ below the surface of a white polyethylene mulch covered raised tomato bed during Fall 2011 and 2013 in Immokalee, FL.

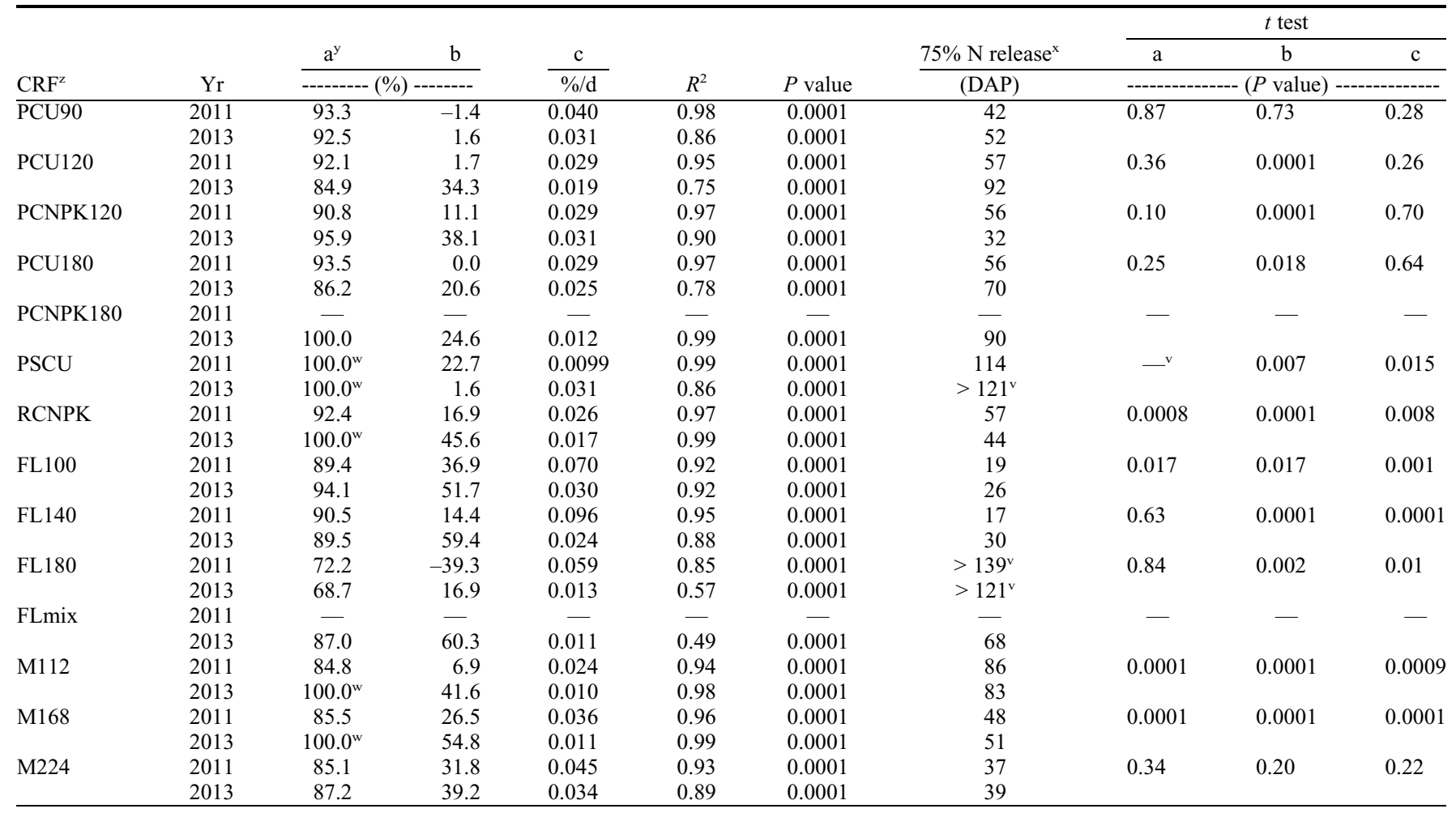

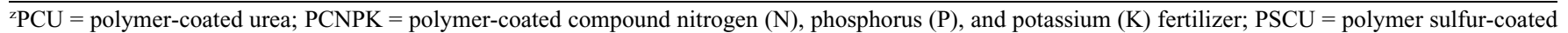

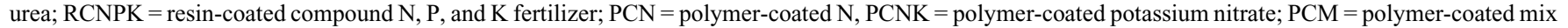
containing FL100, FL140, and FL180; M112, M168, and M224 are mixes of CRF and SF that when applied at $1493 \mathrm{~kg} \cdot \mathrm{ha}{ }^{-1}$ supply 112,168 , and $224 \mathrm{~kg} \cdot \mathrm{ha}^{-1} \mathrm{~N}$. ${ }^{y}$ Percentage $\mathrm{N}$ release $=\mathrm{a}-(\mathrm{a}-\mathrm{b}) * \mathrm{e}^{-\mathrm{ct}}$ where $\mathrm{a}=$ maximum $\mathrm{N}$ release, $\mathrm{b}=\mathrm{N}$ release when time $(\mathrm{t})=0$, and $\mathrm{c}=$ rate of $\mathrm{N}$ release.

${ }^{x} \mathrm{DAP}=$ days after placement.

${ }^{\mathrm{w}}$ The a regression coefficient was restrained to $100 \% \mathrm{~N}$ release.

${ }^{v}$ Extrapolation beyond the season length is not valid.

the greatest SF and filler amounts, compared with M168 and M224 (Carson and Ozores-Hampton, 2013).

Similar to many fertilizers in this study, a CRF study reported that RCNPK and PCNPK release higher $\mathrm{N}$ in the first week of laboratory incubation than any subsequent week and that PNR increased with increasing temperatures from 5 to $45^{\circ} \mathrm{C}$ (Lamont et al., 1987). However, 70-d release polyolefin CRF released $\approx 20 \%$ and $60 \% \mathrm{~N}$ in 50 to $150 \mathrm{~d}$ during a potato (Solanum tuberosum) season, which was slower than the current study as a result of the temperature differences between spring in Minnesota and fall in Florida (Zvomuya et al., 2003). Comparatively, a 70 -d release polyolefin CRF released $18 \%$ to $20 \%$ and $75 \%$ to $80 \%$ of the $\mathrm{N}$ in 30 and $120 \mathrm{~d}$ in Japan, which was lower compared with the PNR found at a similar day after placement (DAP) in this study (Gandeza et al., 1991). Thus, when using CRF in seasons with higher temperatures such as those in Florida and the subtropics, a release duration longer than the season may be necessary to obtain a release pattern similar to crop $\mathrm{N}$ uptake.

Non-linear regression analysis of nitrogen release. As a result of interactions between year and CRF, the CRF nonlinear regression models were presented by year and were highly significant for all CRFs (Table 6). The nonlinear regression model fit the pouch-incubated CRF PNR with $R^{2}=0.85$ to 0.99 during 2011 and 0.49 to 0.99 during 2013. The total season PNR ("a" value) was not different between years for seven of 12 replicated CRFs. The "a" values for the fitted regression model differed from the measured total season PNR less than 3\% for six and four CRFs and lower than 5\% for 10 and six CRFs in 2011 and 2013, respectively. Six of the CRFs that had a $5 \%$ or greater PNR difference, which ranged from $8.4 \%$ to $21.8 \%$, were bound to $100 \% \mathrm{~N}$ release by the regression model as a result of a relatively linear $\mathrm{N}$ release as a result of a high initial release or failure to reach the decay stage of release (Tables 4 and 6). The " $b$ " values were variable with 10 of 12 replicated CRFs having significantly different " $b$ " values between years; however, extrapolation to less than 7 DAP would be invalid, because $\mathrm{t}=0$ data were not used to fit the nonlinear regression model. The " $b$ " or intercept values do not reflect immediately available $\mathrm{N}$, because all $\mathrm{N}$ used in this study was encapsulated. The "c" values ranged from 0.0099 to $0.96 \% / \mathrm{d}$ and 0.010 to $0.034 \% / \mathrm{d}$ during 2011 and 2013, respectively. The $\mathrm{N}$ release rate ("c" value) was similar between years for five of 12 CRFs and significantly lower in six of 12 replicated CRFs in 2013 compared with 2011, which was the result of the lower soil temperature in 2013.
Similar to the pouch-incubated CRF N release results in this study, an exponentialgrowth nonlinear regression model fit $\mathrm{CRF}$ PNR data with a $R^{2} \geq 0.98$ when CRFs were incubated in pouches under orange (Citrus sinensis) trees (Medina, 2006). Zvomuya et al. (2003) instead used quadratic regression to model $\mathrm{N}$ release from pouch-incubated PCU placed in a potato field with a DAP model and a growing-degree day model and found $R^{2}$ of 0.96 and 0.91 , respectively. However, Medina (2006) obtained PNR greater than $90 \%$ during the 360 -d trial, but Zvomuya et al. (2003) found PNR of $60 \%$ during the 150-d trial. The CRF used by Zvomuya et al. (2003) did not reach the decay stage of release, which is the stage of release where the $\psi_{\mathrm{S}}$ begin to equilibrate and release slows; therefore, linear release results may be expected. As a result of the high PNR during the tomato season in the current study, the exponential-growth nonlinear regression was used to model the data.

Days to $75 \%$ nitrogen release. Release of $75 \% \mathrm{~N}$ was obtained in 17 to greater than 139 DAP and 26 to greater than 121 DAP in 2011 and 2013, respectively; thus, all CRFs released with a shorter duration in 2011 than 2013 except RNPK, PCNPK120, and M112 (Table 6). Furthermore, in all cases, $75 \% \mathrm{~N}$ release was accelerated compared with the CRF manufacturer's stated release duration. 


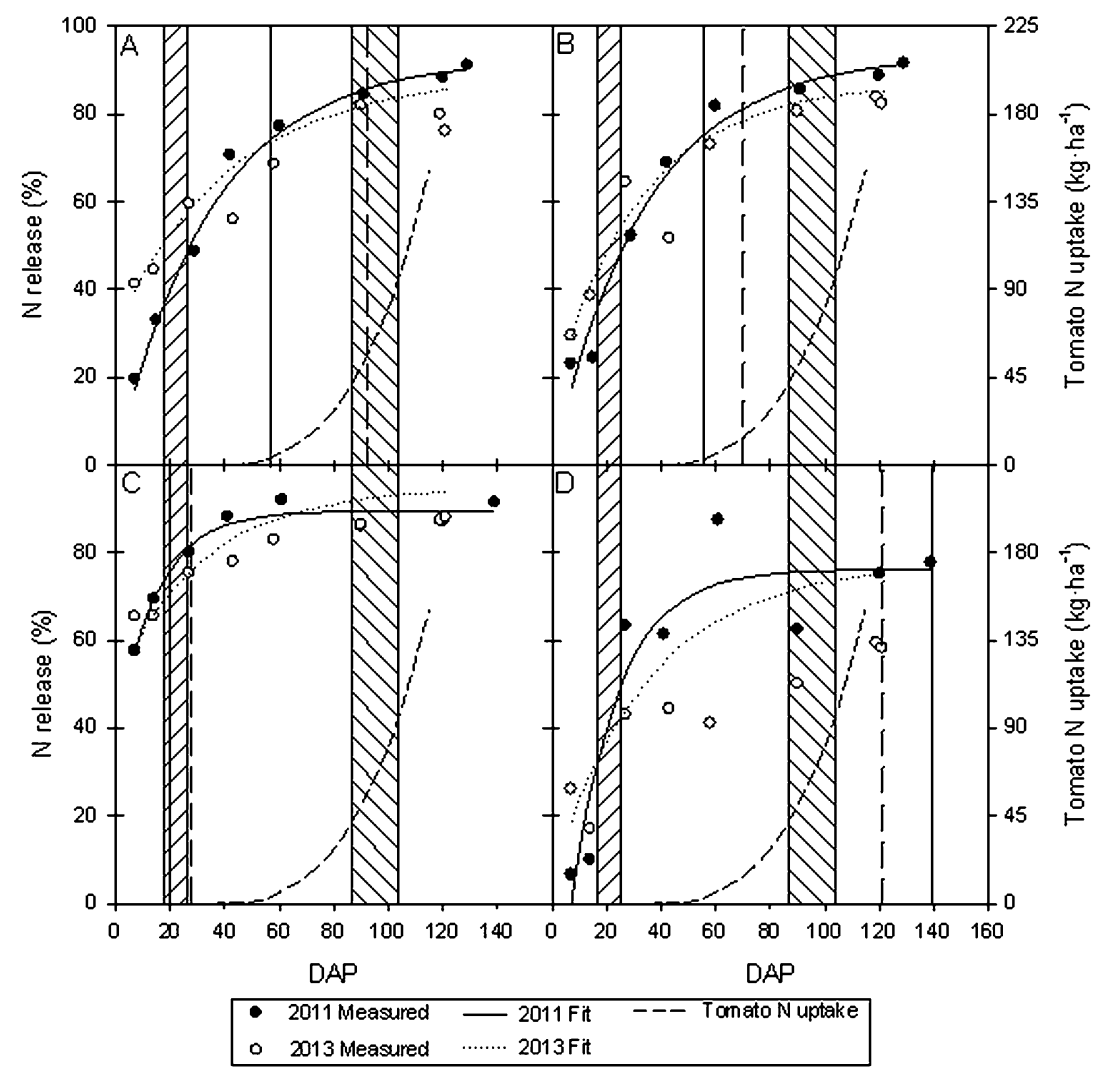

Fig. 1. Measured and fitted nitrogen $(\mathrm{N})$ release from four representative controlled-release fertilizers (CRFs) [polymer-coated urea 120-d release (A) and polymer-coated urea 180-d release (B) from Agrium Advanced Technologies (Loveland, CO), and polymer-coated N 100-d release (C) and polymer-coated potassium nitrate 180-d release (D) from Florikan ESA (Sarasota, FL)]. The forward and backward sloping shaded areas represent the planting and first harvest windows reported by Carson et al. (2014a, 2014b). The solid and dashed vertical lines cross the day after planting axis (DAP) at 75\% $\mathrm{N}$ release in 2011 and 2013, respectively. Tomato N uptake was measured in Immokalee, FL (Scholberg, 1996)

At the manufacturer incubation temperature $\left(20.0^{\circ} \mathrm{C}\right)$, PCU180 has a 60 - and 90 -d longer release duration compared with PCU120 and PCU90; although as a result of higher soil temperatures, $75 \% \mathrm{~N}$ release for PCU180 was 1 and $22 \mathrm{~d}$ shorter compared with PCU120 and 14 and $18 \mathrm{~d}$ longer compared with PCU90 in 2011 and 2013, respectively. In contrast, PCNPK180, which has a 60-d longer release duration compared with PCNPK120 at CRF manufacturer incubation temperature, had a 58-d longer release duration compared with PCNPK120 in 2013. Compared with FL100, FL140 had a 40-d longer release duration at CRF manufacturer temperatures; however, in the fall season, FL140 obtained $75 \% \mathrm{~N}$ release $2 \mathrm{~d}$ before and $4 \mathrm{~d}$ after FL100 in 2011 and 2013, respectively. The fall mixes (M112, $\mathrm{M} 160$, and M224) obtained $75 \% \mathrm{~N}$ release with a difference of $3 \mathrm{~d}$ or lower between years but a 49 - and 44 -d difference in $75 \% \mathrm{~N}$ release was found among the fall mixes and FLmix in 2011 and 2013, respectively. The CRFs composition in the fall mixes and FLmix were equivalent; thus, the included SF and fillers may have affected the osmotic potential and CRF release duration.

Figure 1 shows four CRFs compared with the tomato growing season, which includes an 18- to 26-d lag period between bedding and tomato transplanting as a result of fumigation requirements and a 20 -d first harvest window as found in Carson et al. (2014a, 2014b). During a 26-d lag period, FL100 and FL140 in 2011 and FL100 in 2013 released $75 \%$ of the $\mathrm{N}$ before tomatoes were transplanted. Tomato uptake was $10 \%$ and $30 \%$ of the total season $\mathrm{N}$ in the first 30 and $46 \mathrm{~d}$ after transplant (Scholberg, 1996). Therefore, two and four CRFs in 2011 and one and five CRFs in 2013 released greater than $75 \%$ of the $\mathrm{N}$ before tomatoes uptake $10 \%$ and $30 \%$ season total $\mathrm{N}$, respectively. Furthermore, greater than $50 \%$ of the 2011 season and 3 weeks of the 2013 season included the high rainfall season that ends in mid-October in southwest Florida (Rosencrans, 2012). Thus, between $62.8 \%$ and $90.3 \% \mathrm{~N}$ in 2011 and $27.1 \%$ and $71.6 \% \mathrm{~N}$ in 2013 was released during the high rainfall season in which $\mathrm{N}$ will be subject to leaching as a result of water table fluctuations (Sato et al., 2009, 2012). The 90- and 100-d release CRFs released the majority of the $\mathrm{N}$ during the rainy season and should not be recommended for tomato production during the fall season. Controlled-release fertilizers of $180-\mathrm{d}$ release duration released between $58.3 \%$ and $91.5 \%$ of the $\mathrm{N}$ during the season, but a thicker coating results in a greater cost compared with CRF of lower release durations. Furthermore, 180-d CRFs did not consistently maintain low early-season PNR and high total season PNR compared with CRF of 120-d release. Therefore, CRFs or CRF mixes of 120 to $180 \mathrm{~d}$ may be recommended, although the CRFs and mixes must consistently release a high portion of the total $\mathrm{N}$ to the intended crop.

In conclusion, under the conditions of this study, the PNR from pouch-incubated CRFs in the tomato field was accelerated during the fall season compared with the manufacturer's stated release, which was the result of high soil temperatures that caused coating technologydependent $\mathrm{N}$ release. A CRF or CRF mixture containing CRFs of 120 - to $180-\mathrm{d}$ release duration may be recommended for growing conditions in south Florida, but the CRFs must release greater than $75 \% \mathrm{~N}$ during the season.

\section{Literature Cited}

Agrium Advanced Technologies. 2010. DurationCR Controlled-release fertilizer. 29 Aug. 2013. <http:// agriumat.com/includes/duration_sell_sheet.pdf $>$.

Bartnick, B., G. Hochmuth, J. Hornsby, and E. Simonne. 2005. Water quality/quantity best management practices for Florida vegetable and agronomic crops. Florida Dept. Agr. Consumer Serv., Tallahassee, FL.

Carson, L.C. and M. Ozores-Hampton. 2012. Methods for determining nitrogen release from controlled-release fertilizers used for vegetable production. HortTechnology 22:20-24.

Carson, L.C. and M. Ozores-Hampton. 2013 Factors affecting nutrient availability, placement, rate, and application timing of controlledrelease fertilizers for Florida vegetable production using seepage irrigation. HortTechnology 23:553562.

Carson, L.C., M. Ozores-Hampton, and K.T. Morgan. 2012a. Effect of controlled-release fertilizer on tomatoes grown with seepage irrigation in Florida sandy soils. Proc. Fla. State Hort. Soc. 125:164-168.

Carson, L.C., M. Ozores-Hampton, and J.B. Sartain. 2012b. Controlled-release fertilizer drying methods effect on nitrogen recovery analysis. HortScience 47:S320.

Carson, L.C., M. Ozores-Hampton, and K.T. Morgan. 2013. Nitrogen release from controlled-release fertilizers in seepage-irrigated tomato production in south Florida. Proc. Fla. State Hort. Soc. 126:131-135.

Carson, L.C., M. Ozores-Hampton, K.T. Morgan, and S.A. Sargent. 2014a. Effect of controlledrelease and soluble fertilizer on tomato production and postharvest quality in seepage irrigation. HortScience 49:1-7.

Carson, L.C., M. Ozores-Hampton, K.T. Morgan, and S.A. Sargent. 2014b. Effect of controlledrelease fertilizer nitrogen rate, placement, source, and release duration on tomato grown with seepage irrigation in Florida. HortScience 49:798-806.

Everris. 2013. Osmocote classic. 29 Aug. 2013. $<\mathrm{http}$ ://www.everris.us.com/sites/default/files e90551_.pdf $>$.

Florida Automated Weather Network. 2013. Archived weather data. UF/IFAS, Gainesville, FL.7 June 2013. <http://fawn.ifas.ufl.edu/data/>

Florikan, E.S.A. 2012a. Technologies \& brandsFlorikan. 29 Aug. 2013. <http://florikan.com/ flktech.html>.

Florikan, E.S.A. 2012b. Technologies \& brandsNutricote. 29 Aug. 2013. <http://florikan.com/ nuttech.html>. 
Gandeza, A.T., S. Shoji, and I. Yamada. 1991 Simulation of crop response to polyolefin-coated urea: I. Field dissolution. Soil Sci. Soc. Amer. J. 55:1462-1467.

Huett, D.O. and B.J. Gogel. 2000. Longevities and nitrogen, phosphorus, and potassium release patterns of polymer-coated controlled-release fertilizers at $30^{\circ} \mathrm{C}$ and $40^{\circ} \mathrm{C}$. Commun. Soil Sci. Plant Anal. 31:959-973.

Lamont, G.P., R.J. Worrall, and M.A. O’Connell. 1987. The effects of temperature and time on the solubility of resin-coated controlled-release fertilizers under laboratory and field conditions. Sci. Hort. 32:265-273.

Medina, C. 2006. Nutrient release patterns of coated fertilizers used for citrus production and their effect on fruit yield and foliar nutrition. University of Florida, Gainesville, FL.

Medina, C. 2011. Method development to characterize nutrient release patterns of enhancedefficiency fertilizers. PhD diss., Univ. Florida, Gainesville, FL.

Medina, L.C., T.A. Obreza, J.B. Sartain, and R.E. Rouse. 2008. Nitrogen release patterns of a mixed controlled-release fertilizer and its components. HortTechnology 18:475-480.
Rosencrans, M. 2012. Early start to the 2012 rainy season. Miami-South Florida National Weather Service Forecast Office, Miami, FL.

Sartain, J.B., W.L. Hall, R.C. Littell, and E.W. Hopwood. 2004a. Development of methodologies for characterization of slow-release fertilizers. Proc. Soil Crop Sci. Soc. Fla. 63:72-75.

Sartain, J.B., W.L. Hall, R.C. Littell, and E.W. Hopwood. 2004b. New tools for the analysis and characterization of slow-release fertilizers, p. 180-195. In: Hall, W.L. and W.P. Robarge (eds.). Environmental impact of fertilizer on soil and water. American Chemical Society, Washington, DC.

Sato, S. and K.T. Morgan. 2008. Nitrogen recovery and transformation from a surface or sub-surface application of controlled-release fertilizer on a sandy soil. J. Plant Nutr. 31:2214-2231.

Sato, S., K.T. Morgan, M. Ozores-Hampton, K. Mahmoud, and E.H. Simonne. 2012. Nutrient balance and fertilizer use efficiency in sandy soils cropped with tomatoes under seepage irrigation. Soil Sci. Soc. Amer. J. 76:1867-1876.

Sato, S., K.T. Morgan, M. Ozores-Hampton, and E.H. Simonne. 2009. Spatial and temporal distribution in sandy soils with seepage irrigation:
I. Ammonium and nitrate. Soil Sci. Soc. Amer. J. 73:1044-1052.

Scholberg, J. 1996. Adaptive use of crop growth models to simulate the growth of field-grown tomato. PhD diss., University of Florida, Gainesville, FL.

Shaviv, A. 1996. Plant response and environmental aspects as affected by rate and pattern of nitrogen release from controlled release $\mathrm{N}$ fertilizers, p. 285-291. In: Van Cleemput, O., G. Hofman, and A. Vermoesen (eds.). Progress in nitrogen cycling studies. Kluwer Academic Publishers, The Netherlands.

Trenkel, M.E. 2010. Slow- and controlled release and stabilized fertilizers: An option for enhancing nutrient use efficiency in agriculture. 2nd Ed. IFA, Paris, France.

Wilson, M.L., C.J. Rosen, and J.F. Moncrief. 2009. A comparison of techniques for determining nitrogen release from polymer-coated urea in the field. HortScience 44:492-494.

Zvomuya, F., C.J. Rosen, M.P. Russelle, and S.C. Gupta. 2003. Nitrate leaching and nitrogen recovery following application of polyolefincoated urea to potato. J. Environ. Qual. 32:480489. 